\title{
PENINGKATAN KOMPETENSI GURU DALAM MEMBUAT RPPH MELALUI SUPERVISI KLINIS DI PAUD AS-SAJIDAH DRIYOREJO GRESIK
}

\author{
Nafiah, Sri Hartatik, \\ Universitas Nahdlatul Ulama Surabaya \\ e-mail: nefi_23@unusa.ac.id
}

\begin{abstract}
Abstrak: Tujuan penelitian adalah meningkatkan kompetensi guru membuat RPPH di Paud AsSajidah Driyorejo Gresik melalui supervisi klinis. Penelitian menggunakan penelitian tindakan sekolah (PTS). Pada setiap siklus terdiri dari perencanaan, pelaksanaan, observasi disertai dengan evaluasi dan refleksi. Teknik pengumpulan data yang digunakan adalah checklist dan wawancara. Teknik analisis data yang digunakan adalah analisis data statistik deskriptif dan kualitatif deskriptif. Berdasarkan hasil penelitian tindakan sekolah disimpulkan bahwa supervisi klinis dapat meningkatkan kompetensi guru membuat RPPH. Hal itu dilihat dari peningkatan guru dari siklus ke siklus. Pada pra-siklus kemampuan guru membuat RPPH dari tujuh komponen yang harus ada dalam RPPH menunjukkan nilai rata-rata pe komponen dari guru pada pra siklus adalah $27,6 \%$. Setelah diadakan supervisi klinis, meningkat menjadi 67,6\% pada siklus pertama, dan pada siklus kedua juga mengalami peningkatan pula menjadi $89,49 \%$. Peningkatan tersebut melebihi kriteria keberhasilan penelitian tindakan yang ditargetkan yaitu $81 \%$.
\end{abstract}

Kata kunci: supervisi klinis, kompetensi guru

\begin{abstract}
The purpose of study was to increase the pedagogic competence to make the lesson plan through clinical supervision at As-Sajidah childhood Driyorejo Gresik. The type of this study was school action research. Each action consist of two steps, each steps consist of four steps were (1) planning, (2) acting, (3) observing dan evaluating, dan (4) reflection. The technic of data collecting were interview and checklist. The technic of data analysis were descriptive statistic and qualitative descriptive. Based on the result of this study could be concluded that the clinical supervision can improve teacher competence to make lesson plan for early childhood, it can be seen from the improvement of the teacher from cycle to cycle, on pre cycles, teacher ability in making RPPH of seven components that must exist in RPPH shows the average value of component of teacher in pre cycle is 27,6\%, after clinical supervision, the ability to make RPPH increased to 67, 6\% in the first cycle, and in the second cycle also increased to $89.49 \%$. This result was exceeding the criteria of action research that researchers target is $81 \%$.
\end{abstract}

Keywords: clinical supervision, lesson plan (RPPH), early childhood

\section{PENDAHULUAN}

Guru merupakan faktor penentu berhasil tidaknya pembelajaran. Menurut Kayani, Morris, Azhar and Kayani (2011:169)... teacher is the knight for any educational system, the quality of teacher education would largely depend upon the effectiveness of teacher education institution.
Praktik pengajaran efektif bergantung pada kualitas guru. Dalam praktik masih banyak permasalahan pembelajaran sering dikeluhkan guru seperti kesulitan menyusun dokumen pembelajaran, melaksanakan tugas mengajar menggunakan keterampilan mengajar yang sesuai dengan tuntutan materi pelajaran dan permasalahan lain berkaitan dengan pembelajaran. 
Permasalahan ini terkait dengan pengelolaan pembelajaran yaitu merencanakan, melaksanakan, dan mengevaluasi pembelajaran.

Guru sebelum memulai kegiatan pembelajaran seharusnya membuat rencana pembelajaran yang mengacu pada karakteristik siswa dari aspek usia, sosial, budaya, dan kebutuhan individu anak.

Rencana program harian yang akan dilaksanakan oleh guru pada setiap hari sesuai dengan program lembaga PAUD yang digunakan acuan dalam mengelola kegiatan bermain dalam satu hari disebut dengan RPPH, (Direktorat Pembinaan PAUD, 2014:18-19). Jadi RPPH adalah rencana harian yang disusun oleh pendidik atau pengasuh yang dijadikan acuan dalam mengelola kegiatan bermain anak usia dini sesuai dengan program lembaga masing-masing.

Komponen-komponen rencana pelaksanaan pembelajaran $(\mathrm{RPPH})$ menurut direktorat pembinaan pendidikan anak usia dini (2015:19-24) adalah sebagai berikut.

1. Identitas RPPH yang memuat:
a. nama satuan PAUD
b. semester/bulan/minggu
c. hari/tanggal
d. tema/sub-tema.

2. Materi yang diambil dari materi yang telah dijabarkan di RPPM. Jenis materi dibedakan menjadi materi pengembangan sikap, pengembangan pengetahuan, dan pengembangan keterampilan.

3. Alat dan bahan, yang akan ditata dan dikelola guru untuk menarik minat belajar anak.

4. Kegiatan pembukaan, dilakukan dengan mengenalkan materi pembelajaran, kegiatan bermain, mengenalkan aturan kegiatan bermain, menerapkan pembiasaan yang akan dilakukan oleh anak.

5. Kegiatan Inti, pendekatan saintifik melalui proses mengamati, menanya, mengumpulkan informasi, menalar dan mengomunikasikan kepada anak merupakan kegiatan inti dari pembelajaran. Pada pembelajaran guru menerapkannya dengan fleksibel. Guru juga memfasilitasi anak untuk melakukan eksplorasi membangun pengalaman bermain dan bermakna. Setelah itu, guru mengomunikasikan pada anak dengan menyampaikan hasil gagasannya. Guru juga melakukan penguatan mengingat (recalling), digunakan untuk menguatkan kembali pengalaman bermain anak yang sudah dialami selama kegiatan pembelajaran.

6. Kegiatan penutup yang merupakan akhir dari kegiatan pembelajaran. Pada kegiatan ini, anak diberikan kegiatan yang membuatnya rileks, mengulang kegiatan pada saat pembukaan, kegiatan yang menarik minat anak belajar pada esok hari.

7. Rencana penilaian, dikembangkan dengan mengacu pada indikator perkembangan anak, tujuan pembelajaran. format rencana penilaian anak biasa dikembangkan oleh guru, karena tidak anak format yang baku.

Ada beberapa menyusun RPPH (Direktorat Pembinaan PAUD, 2014:18) adalah sebagai berikut. Guru menyusun RPPH berdasarkan kegiatan mingguan, RPPH berisi kegiatan pembuka, inti, dan penutup, RPPH disusun berdasarkan kondisi PAUD masing-masing, guru menggunakan pendekatan saintifik, tidak ada format baku dalam menyusun RPPH tetapi komponennya disesuaikan dengan pemerintah.

Menurut Acheson and Gall (dalam Sarfo dan Cudjoe, 2016 : 89) "Clinical supervision is a classroom supervision which focuses upon the improvement of instruction by means of systematic cycles of planning, observation and intensive intellectual analysis of actual teaching performance in the interest of rational modification." Supervisi klinis merupakan kegiatan super- 
visi yang difokuskan pada perbaikan pembelajaran guru dengan menggunakan siklus yang sistematis dari perencanaan, pelaksanaan, pengamatan dan analisis intelektual secara intensif terhadap kinerja guru.

Kepala sekolah bisa menggunakan supervisi klinis untuk meningkatkan kemampuan guru dalam membuat RPPH dan mengimplementasikan RPPH tersebut ke dalam suatu pembelajaran, sehingga pembelajaran yang ada di PAUD bisa berjalan sesuai yang direncanakan.

Banyak model supervisi yang bisa digunakan oleh kepala sekolah, tetapi untuk memperbaiki satu-persatu dari kekurangan guru akan lebih efektif jika menggunakan supervisi klinis.

Guru merupakan faktor utama dalam proses peningkatan dan perbaikan pengajaran. Untuk meningkatkan perbaikan dan kualitas seorang supervisor harus bisa melakukan pendekatan dan teknik secara manusiawi. Supervisor harus bisa menempatkan pendekatan dan teknik dalam meningkatkan kinerja guru sesuai dengan situasi dan kondisi. Mempelajari berbagai pendekatan dalam supervisi memungkinkan kepala sekolah mempunyai wawasan yang luas tentang supervisi.

Asumsi dasar supervisi klinis adalah proses sosialisasi harus dilakukan dengan membantu guru secara tatap muka dan individual dengan mengombinasikan target dan pertumbuhan pribadi.

Supervisi klinis adalah proses tatap muka antara supervisor dengan guru yang membicarakan dalam hal mengajar dan ada hubungannya dengan hal itu. Pembicaraan ini bertujuan membantu pengembangan profesional guru dan sekaligus untuk memperbaiki proses pengajaran itu sendiri. Pembicaraan ini biasanya dipusatkan kepada penampilan mengajar guru berdasarkan hasil obeservasi.
Menurut Cogan (Mantja, 2000:159) ada delapan kegiatan dalam supervisi klinis yaitu tahap membangun dan memantapkan hubungan guru-supervisor, perencanaan bersama guru, perencanaan strategi observasi, observasi pembelajaran, analisis proses pembelajaran, perencanaan strategi pertemuan, pertemuan, dan penjajakan rencana pertemuan berikutnya. Berdasarkan pendapat di atas, proses supervisi klinis, ada tiga siklus, yaitu (1) pertemuan awal, (2) observasi, dan (3) pertemuan balikan. Berikut ini adalah siklus pelaksanaan supervisi klinis.

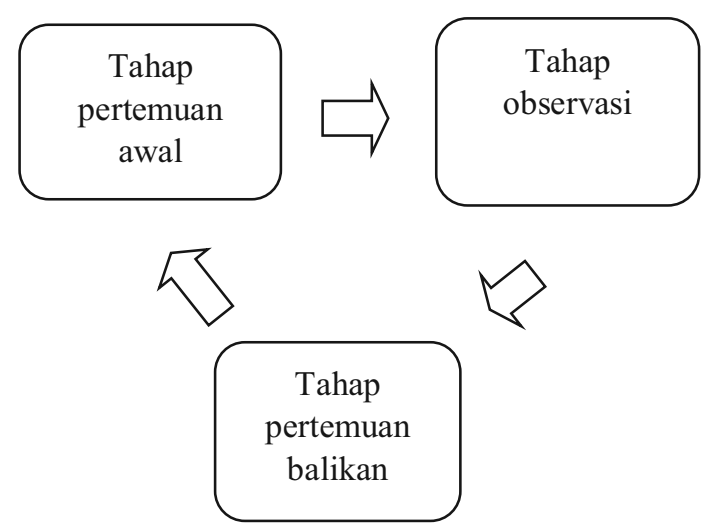

\section{Gambar 1 Langkah-Langkah Pelaksanaan Supervisi Klinis}

Salah satu PAUD yang 80\% gurunya belum bisa menguasai cara membuat RPPH dengan baik adalah PAUD As-Sajidah. Penyebabnya adalah guru kurang memahami komponen-komponen yang harus ada dalam RPPH, cara membuat RPPH yang baik dan benar. Hal tersebut terjadi karena latar belakang pendidikan guru di PAUD As-Sajidah adalah bukan dari lulusan PGPAUD, sehingga penguasaan terhadap pembuatan perangkat pembelajaran masih rendah. Tindakan yang harus dilakukan oleh seorang kepala sekolah dari memecahkan permasalahan tersebut adalah dengan menggunakan tindakan supervisi.

Penggunaan supervisi klinis, diharapkan bisa meningkatkan kemampuan guru dalam membuat $\mathrm{RPPH}$ sehingga tujuan dari pembelajaran bisa 
berjalan sesuai yang direncanakan. Oleh sebab itu, tujuan penelitian adalah meningkatkan kompetensi guru dalam membuat RPPH di Paud AsSajidah Driyorejo Gresik melalui Supervisi Klinis. Penelitian ini merupakan salah satu upaya peneliti dalam bentuk berbagai kegiatan yang dilakukan untuk memperbaiki dan meningkatkan mutu guru di PAUD As-Sajidah.

\section{METODE PENELITIAN}

Penelitian ini menggunakan dua pendekatan kualitatif dan kuantitatif. Jenis penelitian ini adalah penelitian tindakan sekolah merupakan rangkaian tindakan digunakan untuk memecahkan masalah. Penelitian ini dilakukan selama 1 bulan dimulai sejak 19 Juli sampai 19 Agustus 2017. Pelaksanaan pra tindakan dilaksanakan pada 22 Juli 2017, pelaksanaan siklus I dilaksanakan pada 28 Juli-5 Agustus 2017 dan pelaksanaan siklus II dilaksanakan pada 7-19 Juli 2017. Tempat penelitian ini di PAUD As-Sajidah Driyorejo Gresik.

\section{Siklus Pertama}

\section{Perencanaan}

Pada tahap ini, kegiatan yang dilakukan adalah sebagai berikut.

a. Meminta guru mengemukakan kesulitan dalam menyusun RPPH.

b. Merumuskan masalah yang akan dicari solusinya.

c. Merumuskan tujuan penelitian.

d. Merumuskan indikator keberhasilan penelitian.

e. Merumuskan langkah-langkah kegiatan penelitian.

f. Menyusun instrumen pengamatan dan evaluasi. g. Menentukan waktu dan tempat pelaksanaan penelitian.

\section{Pelaksanaan}

Pada tahap ini peneliti melaksanakan rencana tindakan supervisi klinis pada setiap guru di PAUD As-Sajidah untuk menilai RPPH guru yang sudah dibuat sebelumnya. Kegiatan pertama dimulai dengan pertemuan individual melalui tiga kegiatan yaitu pertemuan awal, observasi dan pertemuan balikan. Hal ini dilakukan untuk memberikan bimbingan kepada guru cara menyusun RPPH yang baik. Kegiatan ini dilakukan selama 1 minggu.

\section{Pengamatan dan Evaluasi}

Dalam melakukan pengamatan, digunakan instrumen yang berisi indikator-indikator proses tindakan. Evaluasi merupakan proses menentukan hasil dari pelaksanaan supervisi yang telah dilaksanakan yang sesuai indikator-indikator tujuan PTS yang telah ditetapkan. Hasil evaluasi digunakan sebagai dasar melakukan refleksi. Pada kegiatan ini dilakukan pengamatan terhadap seluruh kejadian yang terjadi selama tahap pelaksanaan dan mengobservasi hasil awal yang dicapai pada pelaksanaan tindakan siklus 1 . Kegiatan yang dilakukan adalah sebagai berikut.

\section{Refleksi}

Untuk mengetahui hasil dari proses pelaksanaan tindakan yang telah dilakukan, maka dilakukan refleksi. Hasil dari refleksi akan dijadikan dasar untuk memperbaiki tindakan pada siklus selanjutnya. Setelah dilakukan refleksi, maka dilanjutkan dengan pertemuan bersama kolaborator untuk membahas hasil evaluasi dan penyusunan langkah-langkah untuk siklus kedua. 
Instrumen yang digunakan lembar pengamatan perangkat pembelajaran/RPPH. Instrumen dipergunakan untuk menilai RPPH yang sudah dikerjakan guru sesuai dengan komponen atau tidak.

Teknik pengumpulan data pada penelitian tindakan sekolah adalah menggunakan wawancara dan checklist dilakukan peneliti menilai dalam Rencana Pelaksanaan Pembelajaran Harian di PAUD As-Sajidah. Analisis data menggunakan analisis data statistik deskriptif dan kualitatif deskriptif.

\section{HASIL DAN PEMBAHASAN}

Hasil pra-siklus dari tiga guru di PAUD Assajidah, diperoleh informasi bahwa semua guru (tiga orang) belum mengetahui kerangka penyusunan RPPH, sekolah yang memiliki dokumen program tahunan, program semester. $\mathrm{RPPH}$ sekolah masih belum lengkap. Berdasarkan hasil wawancara guru-guru menyatakan belum memahami cara membuat RPPH yang sesuai. Hal ini dikarenakan kualifikasi pendidikan guru tidak ada yang lulusan S1 PGPAUD. Hanya ada satu orang guru yang pernah mengikuti pelatihan pengembangan RPPH yaitu kepala sekolah.

Berdasarkan hasil pengamatan dan evaluasi terhadap tiga RPPH yang dibuat guru, diperoleh informasi bahwa masih ada guru yang tidak melengkapi RPPH-nya dengan komponen tertentu, misalnya identitas program, materi, alat dan bahan, rencana penilaian. Komponen yang sudah dibuat adalah kegiatan pendahuluan, inti dan penutup.

Berikut ini adalah hasil analisis statistik deskriptif pra siklus guru-guru PAUD As-Sajidah Driyorejo Gresik dari tujuh komponen $\mathrm{RPPH}$ yang ada di PAUD.
Tabel 1 Rekapitulasi Pra-Siklus Tingkat Pemahaman Guru dalam Menyusun RPPH

\begin{tabular}{|c|c|}
\hline Komponen RPPH & Persentase \\
\hline Identitas program & $20 \%$ \\
\hline Materi pembelajaran & $20 \%$ \\
\hline Alat dan bahan & $20 \%$ \\
\hline Kegiatan pembukaan & $46,6 \%$ \\
\hline Kegiatan inti & $40 \%$ \\
\hline Kegiatan penutup & $46,6 \%$ \\
\hline Rencana penilaian & $20 \%$ \\
\hline Rata-rata & $27,6 \%$ \\
\hline
\end{tabular}

Siklus pertama terdiri dari: (1) perencanaan, (2) pelaksanaan, (3) penamatan dan evaluasi, dan (4) refleksi seperti berikut ini.

\section{Perencanaan (Planning)}

Pada tahap ini, dilakukan kegiatan sebagai berikut.

a. Memberi kesempatan kepada guru untuk mengemukakan kesulitan atau hambatan dalam menyusun RPPH. Guru mengemukakan kesulitannya dalam membuat RPPH karena tidak mengetahui cara membuat RPPH yang benar.

b. Mengidentifikasi permasalahan yang ditemukan. Masalah yang dihadapi guru disebabkan karena kurangnya pengetahuan guru dalam membuat RPPH yang benar.

c. Menyusun langkah-langkah pelaksanaan supervisi klinis.

\section{Pelaksanaan (Acting)}

Pada saat awal siklus pertama indikator pencapaian hasil dari setiap komponen RPP belum sesuai/tercapai seperti rencana/keinginan peneliti. Hal itu dibuktikan dengan masih adanya komponen RPP yang belum dibuat oleh guru. 
Pada tahap tindakan dilakukan pertemuan awal, pengamatan, pertemuan balikan.

a. Pertemuan awal dilakukan dengan cara-cara sebagai berikut.

1) Menciptakan suasana yang akrab dan terbuka.

2) Mengidentifikasi aspek-aspek/semua komponen dalam yang akan dikembangkan guru dalam membuat RPPH.

3) Mengidentifikasi prosedur untuk memperbaiki kemampuan guru dalam membuat RPPH melalui bimbingan individu.

4) Membantu guru memperbaiki tujuannya sendiri dalam membuat RPPH.

5) Menetapkan waktu mengumpulkan RPPH.

6) Membuat instrumen penilaian RPPH yaitu lembar penilaian berupa lembar pengamatan dengan menggunakan skala likert.

7) Membuat kesepakatan kepada guru tentang tema yang akan dinilai yaitu tema diri sendiri.

b. Observasi/pelaksanaan supervisi

Tahap kedua dalam proses supervisi klinis adalah tahap observasi dalam penelitian ini, Peneliti tidak melakukan observasi mengajar tapi hanya melakukan penilaian terhadap RPPH yang sudah dibuat guru secara sistematis dan objektif. Waktu yang dipilih adalah hari Sabtu setelah selesai pembelajaran di PAUD dan tema yang dipilih adalah tema diri sendiri, cara penilaian dalam membuat RPPH sudah disepakati bersama oleh supervisor dan guru dalam pertemuan awal.

c. Pertemuan balikan

Pertemuan balikan dilaksanakan setelah observasi RPPH terhadap guru dilakukan. Analisis terhadap hasil observasi dilakukan dalam pertemuan balikan dan hasilnya digunakan untuk menindaklanjuti pelaksanaan supervisi klinis pada guru. Supervisor melakukan bimbingan kepada guru-guru secara individu untuk mem- perbaiki kekurangan guru satu-persatu dalam membuat RPPH.

\section{Pengamatan dan Evaluasi}

Hasil pengamatan dan evaluasi pada siklus kesatu dideskripsikan pada gambar berikut ini.

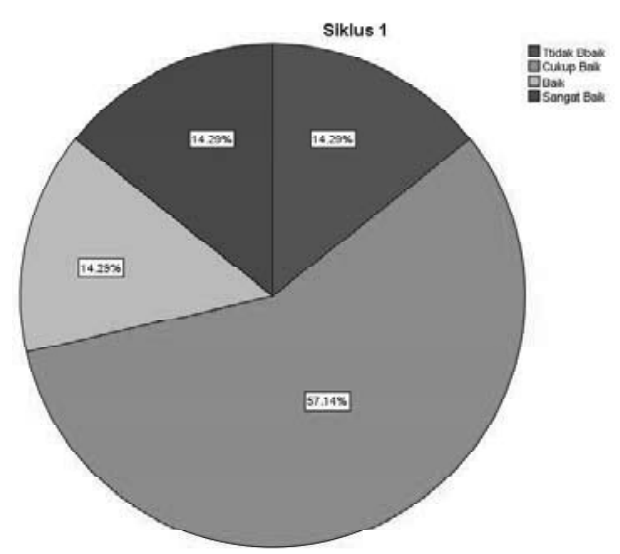

Gambar 2 Persentase Tingkat Pemahaman Guru dalam Membuat RPPH pada Siklus 1

\section{Refleksi}

Berdasarkan analisis hasil pengamatan dan evaluasi pada siklus 1 guru mngala peningkatan dari pra-siklus ke siklus 1, pada pra-siklus kemampuan guru dalam membuat RPPH dari tujuh komponen yang harus ada dalam RPPH menunjukkan 57.1\% kurang baik dan 42.9\% tidak baik, setelah dilakukan supervisi klinis pada siklus 1 meningkat $14.3 \%$, tidak baik 57.1\% cukup baik, $14.3 \%$, baik $14.3 \%$ sangat baik. Hal tersebut dikarenakan guru masih kebingungan dengan pembuatan RPPH yang baik dan benar, masih terdapat beberapa komponen yang guru belum bisa tuliskan secara baik, seperti pada komponen rencana penilaian, guru masih bingung membuat rubrik penilaian. Berdasarkan kekurangan-kekurangan yang terjadi pada siklus I yang belum mencapai indikator pencapaian tindakan 81\% komponen RPPH bisa dibuat dengan baik, maka akan dilakukan perbaikan 
dalam pelaksanaan supervisi pada siklus II agar kompetensi guru dalam membuat RPPH dengan baik. Hal-hal yang perlu dilakukan untuk memperbaiki supervisi pada siklus berikutnya antara lain dengan cara: (a) memberikan arahan guru cara membuat rubrik penilain dengan baik dengan memberi penjelasan ulang kepada masingmasing guru secara individu, (b) mendampingi guru membuat RPPH dan mengarahkannya, (c) memberikan arahan kepada guru untuk membuat RPPH pada aspek yang berbeda agar guru bisa terus latihan, d) Memberi motivasi guru agar siswa selalu berusaha mengerjakan sendiri tidak copy paste dari internet atau orang lain dalam membuat RPPH.

Tabel 2 Rekapitulasi Siklus 1 Tingkat Pemahaman Guru dalam Menyusun RPPH

\begin{tabular}{|l|c|}
\hline \multicolumn{1}{|c|}{ Komponen RPPH } & Persentase \\
\hline Identitas program & $100 \%$ \\
\hline Materi pembelajaran & $73,4 \%$ \\
\hline Alat dan bahan & $60 \%$ \\
\hline Kegiatan pembukaan & $66,6 \%$ \\
\hline Kegiatan inti & $60 \%$ \\
\hline Kegiatan penutup & $66,6 \%$ \\
\hline Rencana penilaian & $46,6 \%$ \\
\hline Rata-rata & $67,6 \%$ \\
\hline
\end{tabular}

Siklus kedua terdiri dari empat tahap yakni: (1) perencanaan, (2) pelaksanaan, (3) pengamatan dan evaluasi, dan (4) refleksi.

\section{Perencanaan (Planning)}

Pada tahap ini, kegiatan yang dilakukan adalah sebagai berikut.

a. Memberi kesempatan kepada guru untuk mengemukakan kesulitan atau hambatan dalam menyusun RPPH pada siklus pertama.

b. Mengidentifikasi permasalahan yang ditemukan dari hasil refleksi pada siklus pertama. Masalah yang dihadapi guru karena masih kebingungan dalam membuat kegiatan pembukaan, kegiatan inti dan kegiatan penutup serta rubrik penilaian.

c. Menyusun langkah-langkah pelaksanaan supervisi klinis, berikut ini langkah-langkahnya supervisi klinis.

\section{Pelaksanaan (Acting)}

Pada saat awal siklus pertama indikator pencapaian hasil dari setiap komponen RPP belum sesuai/tercapai seperti rencana/keinginan peneliti. Hal itu dibuktikan dengan masih adanya komponen RPP yang belum dibuat oleh guru. Pada tahap tindakan peneliti dilakukan pertemuan awal, pengamatan, pertemuan balikan.

a. Pertemuan awal. Pada pertemuan awal dilakukan supervisi klinis terhadap guru yang nilainya masih rendah dalam pembuatan. Kegiatan yang dilakukan adalah sebagai berikut.

1) Menciptakan suasana yang akrab dan terbuka.

2) Mengidentifikasi aspek-aspek yang akan ditingkatkan guru dalam membuat RPPH.

3) Mengidentifikasi prosedur untuk memperbaiki kemampuan guru dalam membuat $\mathrm{RPPH}$.

4) Menetapkan waktu mengumpulkan RPPH.

5) Membuat instrumen penilaian RPPH.

b. Observasi/pelaksanaan supervisi. Tahap kedua dalam proses supervisi klinis adalah tahap observasi dalam penelitian ini, Peneliti melakukan penilaian terhadap RPPH yang sudah dibuat guru secara sistematis dan objektif. Waktu sudah disepakati antara masing-masing supervisor dengan guru dan tema yang digunakan masih tetap tema diri sendiri, cara penilaian dalam membuat RPPH sudah disepakati bersama oleh supervisor dan guru dalam pertemuan awal. Pada siklus kedua ini peneliti hanya memperbaiki komponen kegiat- 
an pembukaan, kegiatan inti dan rencana penilaian sesuai yang ditemukan pada siklus pertama yang masih kurang baik. Peneliti melakukan supervisi klinis melalui tiga tahapan tersebut kepada satu persatu guru untuk meningkatkan kekurangannya dalam membuat RPPH dengan komponen yang baik dan lengkap.

c. Pertemuan balikan. Pertemuan balikan dilakukan segera setelah melaksanakan observasi/ pengamatan RPPH guru, dengan terlebih dahulu dilakukan analisis terhadap hasil observasi. Dalam pertemuan balikan pada siklus kedua dipaparkan hasil observasi guru dan tidak ada tindak lanjut karena hasil dari pembuatan RPPH yang sudah dikerjakan guru sudah sangat baik.

\section{Pengamatan dan Evaluasi}

Pada siklus II ini guru sudah menunjukkan perubahan yang signifikan dari siklus I. Hal ini terlihat dari pengamatan dan evaluasi dari $\mathrm{RPPH}$ yang dibuat guru rata-rata sudah baik dan sangat baik pada setiap komponen berikut ini hasil pengamatan dan evaluasi pada siklus kedua yang dilaksanakan pada 29 Juli 2017 dideskripsikan pada gambar di bawah ini.

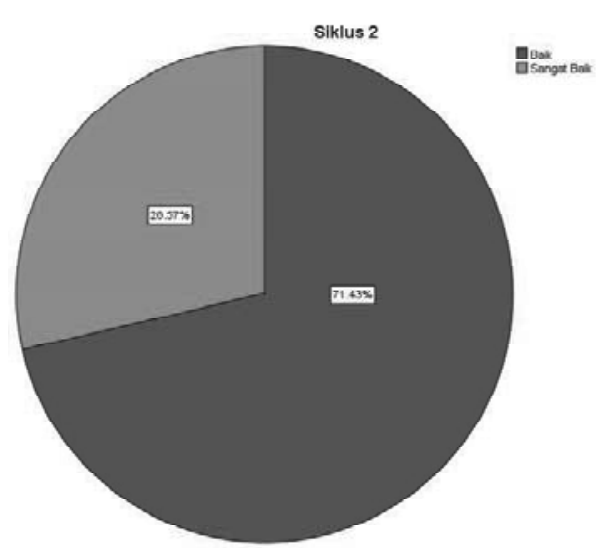

Gambar 3 Persentase Tingkat Pemahaman Guru dalam Membuat RPPH pada Siklus 2

\section{Refleksi}

Setelah kegiatan supervisi klinis selesai peneliti mengadakan diskusi dengan kepala sekolah tentang kegiatan supervisi klinis yang telah dilakukan. Pada kegiatan akhir supervisi klinis, guru sudah memahami komponen-komponen yang ada pada RPPH dan bisa membuat RPPH dengan baik bahkan beberapa orang sudah sangat baik.

Berdasarkan analisis siklus II semua guru sudah sesuai dengan indikator ketercapaian tindakan yang sudah direncanakan. Siklus 2 peningkatannya 71.4\% komponen RPPH dibuat dengan baik dan 28.6\% komponen RPPH di buat dengan sangat baik. Berikut ini adalah tabel hasil peningkatan pada siklus 2 .

Tabel 3 Rekapitulasi Siklus 2 Tingkat Pemahaman Guru dalam Menyusun RPPH

\begin{tabular}{|l|c|}
\hline \multicolumn{1}{|c|}{ Komponen RPPH } & Persentase \\
\hline Identitas program & $100 \%$ \\
\hline Materi pembelajaran & $86,6 \%$ \\
\hline Alat dan bahan & $100 \%$ \\
\hline Kegiatan pembukaan & $86,6 \%$ \\
\hline Kegiatan inti & $86,6 \%$ \\
\hline Kegiatan penutup & $86,6 \%$ \\
\hline Rencana penilaian & $80 \%$ \\
\hline Rata-rata & $89,49 \%$ \\
\hline
\end{tabular}

\section{KESIMPULAN DAN SARAN}

\section{Kesimpulan}

Berdasarkan pembahasan di atas dapat disimpulkan sebagai berikut.

Supervisi klinis dapat meningkatkan kompetensi guru dalam membuat RPPH, hal tersebut bisa dilihat dari peningkatan guru dari siklus ke siklus, pada pra siklus kemampuan guru dalam membuat RPPH dari tujuh komponen yang harus ada dalam RPPH menunjukkan nilai ratarata per komponen dari guru pada pra siklus 
adalah 27,6\%, kemudian meningkat menjadi 67,6\% pada siklus pertama, dan pada siklus kedua juga mengalami peningkatan menjadi 89,49\% melebihi kriteria keberhasilan penelitian tindakan yang peneliti targetkan yaitu $81 \%$.

\section{Saran}

1. Kepala sekolah selaku supervisor bisa menggunakan supervisi klinis karena supervisi ini cocok untuk memperbaiki kelemahan-kelemahan yang ada pada guru dalam proses pembelajaran.

2. Guru hendaknya mengetahui komponen-komponen yang ada pada RPPH sesuai yang telah ditetapkan pemerintah.

\section{DAFTAR PUSTAKA}

. 2014. Pedoman Penyusunan Perencanaan Pembelajaran Pendidikan Anak Usia Dini. Jakarta: Direktorat Pembinaan Pendidikan Anak Usia Dini. . 2010. Penelitian Tindakan Sekolah. Jakarta: Direktorat Kependidikan.
. 2010. Penelitian Tindakan Sekolah. Jakarta: Direktorat Tenaga Kependidikan Direktorat Jenderal Peningkatan Mutu Pendidik dan Tenaga Kependidikan Kementerian Pendidikan Nasional. - 2016. Supervisi Akademik. Jakarta: Direktorat Jenderal Guru dan Tenaga Kependidikan, Kementerian Pendidikan, dan Kebudayaan Republik Indonesia.

Alfonso, R.J., Firth, G.R., dan Neville, R.F. 1981. Instructional Supervision, a Behavior System. Boston: Allyn and Bacon, Inc.

Kayani, Munir, M, Morris, Azhar, D., and Kayani, A. 2011. Analysis of Professional Competency Enhancement Program of Nahe on the Performance of College Teacher. International journal of business and social science. 2 (8):169.

Mantja, M. 2000. Bahan Ajar, Model Pembinaan/ Supervisi Pengajaran. Malang: Pps UM.

Sarfo, F.K. dan Cudjoe, B. 2016. Supervisor Knowledge and Use of Clinical Supervision to Promote Teacher Performance in Basic School. International Journal of Education and Research, (1):87. 
Education and Human Development Journal, Vol. 3, No. 1, April 2018 